\title{
Long term treatment with omalizumab in adolescent with refractory solar urticaria
}

\author{
Mauro lannelli ${ }^{1}$, Stefano Passanisi ${ }^{1}$, Giuseppe Crisafulli ${ }^{1}$, Stefania Arasi ${ }^{2}$, Lucia Caminiti ${ }^{1}$, Giuseppina Zirilli ${ }^{1}$ and
} Giovanni B. Pajno ${ }^{1 *}$ (D)

\begin{abstract}
Background: Solar urticaria represents an uncomfortable form of chronic inducible urticaria. First and second-line treatments are ineffective in some patients, leading to an impairment in their quality of life. Omalizumab represents a safe therapeutic option in case of refractory solar urticaria.

Case presentation: We update a case of a 21-year-old Caucasian girl affected by solar urticaria from the age of 14 . Poor disease control was achieved with standard or high-dose of $\mathrm{H}_{1}$-antihistamines. Several omalizumab courses, including a 1-year-long course, were practiced resulting in clinical remission and significant improvement in patient's quality of life.

Conclusion: Our experience confirms the effectiveness and safety of omalizumab for the management of refractory solar urticaria. Future studies are awaited in order to monitor long term effects and chronic doses of this treatment, particularly in patients who need concomitant therapy with antihistamines.
\end{abstract}

Keywords: Anti-lgE, Chronic inducible urticaria, Management, Quality of life

\section{Background}

Solar urticaria (SU) represents a quite rare but uncomfortable form of chronic inducible urticaria. It is caused by sun-exposure and ultraviolet (UV) irradiation, UVB and more frequently UVA. Skin manifestations usually appear after few minutes of sunlight exposure. Because of its rarity, there are few data on the prevalence and incidence. SU usually manifests itself in the fourth decade of life and it occurs more commonly in women than men, regardless skin phototype and ethnicity [1]. First line treatment is based on second-generation $\mathrm{H}_{1}$-antihistamines, which can be increased up 2-4 fold the standard dosage to achieve clinical remission. However, standard therapy with antihistamines is ineffective in some patients; therefore, these patients require second

\footnotetext{
* Correspondence: giovanni.pajno@unime.it

${ }^{1}$ Department of Human Pathology in Adult and Developmental Age

"Gaetano Barresi", Allergy Unit, University of Messina, Via Consolare Valeria 1, 98124 Messina, ME, Italy

Full list of author information is available at the end of the article
}

and third-line therapeutic approaches (e.g. antileukotrienes, cyclosporine-A, biologics) along with absolute avoidance of sun exposure. The disease-related limitation of normal daily activity frequently leads to an impairment in quality of life of patients. Omalizumab, a recombinant humanized anti-IgE monoclonal antibody approved for the management of chronic spontaneous urticaria and severe asthma, has been recently demonstrated as a safe and effective therapeutic option in patients with inadequate response to standard therapies [2-5]. In Italy, omalizumab is approved for use in chronic spontaneous urticarial, but it is considered offlabel for the management of chronic inducible urticaria, including SU [6].

\section{Case presentation}

We update a previously described case of a 21-year-old Caucasian girl suffering from SU from the age of 14 [7]. She was firstly treated with three $\mathrm{H}_{1}$-antihistamines at standard dose for a total of 8 months (cetirizine $10 \mathrm{mg}$ / 
day, desloratadine $5 \mathrm{mg} /$ day and hydroxyzine $25 \mathrm{mg} /$ day) with unsatisfactory response to therapy. Treatment with $\mathrm{H}_{1}$-antihistamine at double dose (cetirizine $20 \mathrm{mg}$ /day) associated to with $\mathrm{H}_{2}$-antihistamine at standard dose (ranitidine $150 \mathrm{mg} /$ day) and antileukotriene (montelukast $10 \mathrm{mg} /$ day) was also ineffective. During the first 2 years of disease, several 5-day courses of oral prednisone (25 $\mathrm{mg}$ daily) were prescribed as add-on therapy. However, the patient had a poor disease control. At the age of 16 she underwent a 9-month course of experimental therapy with omalizumab subcutaneously, with a starting dose of $375 \mathrm{mg}$ every 2 weeks for 6 months which was progressively decreased to a monthly $150 \mathrm{mg}$ maintenance dose up to suspension. Therapeutic response of the patient had been promptly obtained after the first administration and clinical improvement persisted when maintenance dose had been practiced. Clinical remission was confirmed by the negative results of photo-test for UVA and UVB which was performed at the end of omalizumab course and after 4 months from discontinuation of therapy (Fig. 1).

During the subsequent 4 years, the patient underwent a total of 4 courses of subcutaneous omalizumab due to recurrent relapses of SU after sun exposure. Laboratory tests, including serum IgE levels, eosinophil count, inflammation markers and antinuclear antibodies, were performed at the beginning of each course. Disease activity was monitored by the Urticaria Activity Score over 7 days (UAS7). The first three therapeutic courses were practiced at the dose of $300 \mathrm{mg}$ monthly for a total of 6 months. During treatment cutaneous symptoms faded to a complete remission, as demonstrated by the reduction of UAS7 score values (Fig. 1). Short treatment with second-generation antihistamines at standard dose was occasionally required during omalizumab course due to the appearance of mild cutaneous manifestations (rupatadin $10 \mathrm{mg} /$ day or bilastine $20 \mathrm{mg} /$ day) (Table 1 ).

Symptoms appeared within just 1 month from the last administration of the third omalizumab therapeutic course. Thus, we decided to prescribe a prolonged course of treatment. The girl underwent omalizumab therapy at the previous tested effective dose of $300 \mathrm{mg}$ monthly for 1 year continuously. The aim of this long lasting treatment was to achieve a more sustained response and persistent remission, according to scientific evidence $[8,9]$.

A complete clinical remission reconfirmed to be gained starting from the third dose and was associated with a sustained negativity of UAS7 values. At the 10th month of this treatment, standard dose of anti-histamines (rupatadin $10 \mathrm{mg} /$ day for 7 days and following bilastine $20 \mathrm{mg} /$ day for 7 days) was successfully practiced due to the appearance of two small flares resulting in itch and moderate sunlight-induced erythema. Photo-tests performed at the end of therapy resulted negative. No adverse effects were detected during all the omalizumab courses. Dermatology Life Quality Index (DLQI) questionnaire was completed by the patient to assess the impact of SU on quality of life prior to omalizumab treatment, at the end of both the first and last omalizumab courses. DLQI score was 24, 12 and 9 , respectively, confirming a significant reduction of the emotional burden of the disease.

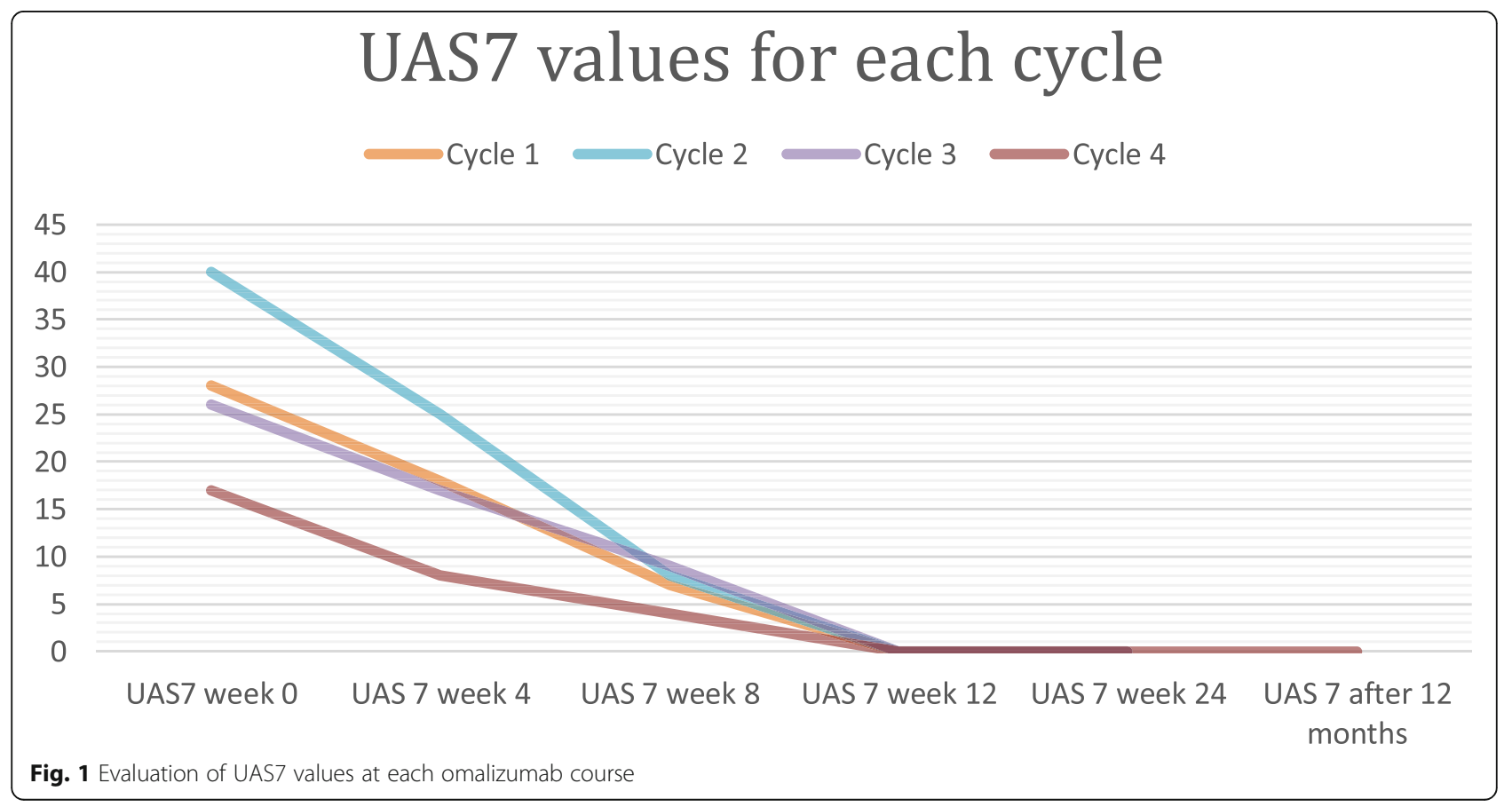


Table 1 Occasional relapses of SU during the 4-year period of follow-up and required treatment

\begin{tabular}{|c|c|c|c|c|}
\hline & $\begin{array}{l}\text { Cycle } \\
1\end{array}$ & Cycle 2 & $\begin{array}{l}\text { Cycle } \\
3\end{array}$ & Cycle 4 \\
\hline Number of flares & 0 & 2 & 0 & 2 \\
\hline Clinical manifestations & - & Erythema/Mild itch & - & Erythema, hives, angioedema/mild itch \\
\hline Treatment description & - & $\begin{array}{l}\text { Rupatadine ( } 10 \mathrm{mg} / \text { day for } \\
14 \text { days) }\end{array}$ & - & $\begin{array}{l}\text { Rupatadine ( } 10 \mathrm{mg} / \text { day for } 7 \text { days) Bilastine }(20 \mathrm{mg} / \\
\text { day for } 7 \text { days) }\end{array}$ \\
\hline $\begin{array}{l}\text { Remission interval after last administration } \\
\text { (months) }\end{array}$ & 4 & 3 & 1 & 4 \\
\hline
\end{tabular}

\section{Discussion and conclusion}

Omalizumab is a recombinant humanized monoclonal antibody that binds to the $\mathrm{CH} \varepsilon 3$ region of $\mathrm{IgE}$ and, thus, avoids IgE from binding to FceRI and FceRII receptors on the surface of mast cells and basophils [10]. Omalizumab also prevents IgE from binding to FceRI on dendritic cells and this could be related to a decreased release of inflammatory mediators with subsequent inhibitory effects on the allergen cascade [11]. Long-term therapy with omalizumab has been approved for the management of moderate to severe asthma and allergic rhinitis. It is also considered effective and safe in treating vernal keratoconjunctivitis and as an add-on maintenance treatment of nasal polyps [12-14]. The 2017 EAAC I/GA2LEN/EDF/WAO international guidelines recommend the use of omalizumab as third-line of treatment for the management of CSU in adults and adolescents aged $\geq 12$ years with inadequate response to $\mathrm{H}_{1}$-antihistamines [15]. Omalizumab use in patients younger than 12 years is still off-label for CSU despite emerging data suggesting safety and efficacy in this population [16].

Regarding chronic inducible urticaria, including SU, there are sparse reports on the use of omalizumab both in adult and pediatric patients $[17,18]$. A recent systematic review, covering a total of 48 patients with antihistamine refractory SU, reported that treatment with omalizumab resulted in clinical improvement for $80 \%$ of patients, and $50 \%$ of them became symptom free. About $20 \%$ of patients failed to achieve any clinical response under a monthly dosage of 150-300 mg of omalizumab. Mild adverse events (i.e. gastrointestinal intolerance, periorbital edema, local reaction, and short-term asthenia) were recorded in only $11 \%$ of subjects [8]. However, most studies have short follow-up periods which are limited to a few months.

To the best of our knowledge, this is the first report describing a 4-year follow-up on omalizumab use to treat an adolescent patient with refractory SU. Our case confirms the rapid clinical efficacy and safety of $300 \mathrm{mg}$ monthly dose. Noteworthy, a similar experience of longterm therapy with omalizumab plus low dose antihistamines has been reported in a child with $\mathrm{SU}$ who was treated for 36 months resulting in clinical remission [8]. In recent years, research teams marked the importance to identify reliable biomarkers which are able to predict changes in disease activity as treatment response. Among these, baseline IgE levels appear to be the most intriguing factor. Some studies showed that among patients with chronic urticaria, non-responders to omalizumab had significantly lower baseline IgE levels than partial responders and complete responders [19, 20]. More specifically, low baseline serum IgE $<15.2$ IU/ $\mathrm{mL}$ would predict a lower likelihood of response to omalizumab [19]. Our case supports this finding since IgE values varied from 73.7 to $224.5 \mathrm{IU} / \mathrm{ml}$ before each therapeutic course, thus defining our patient as a fullresponder.

Another relevant aspect that should be taken into account in SU patients is the psychological impact. Quality of life impairment is quite common among adults and children suffering from SU, especially during relapse times [21]. Can et al. have recently demonstrated that omalizumab not only provides symptom control for chronic urticaria but also improves patients' psychological conditions, thereby making the disease less hard to manage [22]. Likewise, our patient reported a progressive improvement in quality of life as demonstrated by the reduction of DLQI questionnaire scores.

Finally, our experience regarding the last one-year course contributes to support information on efficacy, safety, and tolerability of a prolonged therapeutic regimen and strengthens the awareness that SU cases unresponsive to topical treatment and cyclosporin may need omalizumab $[6,8,9]$. However, unavoidable short exposure to UV, especially in sunny countries, facilitate the occurrence of recurrent relapses of SU after omalizumab discontinuation. In this context, the need of sustained omalizumab treatment at low dosage should be considered in the near future. Therefore, randomized controlled trials with long lasting follow-up are awaited to monitor the chronic doses of omalizumab and schedules for eligible patient suffering from solar urticaria unresponsive to conventional treatment.

Abbreviations

DLQI: Dermatology Life Quality Index; SU: Solar Urticaria; UV: Ultraviolet; UAS: Urticaria Activity Score 


\section{Acknowledgements}

Not applicable.

\section{Authors' contributions}

$\mathrm{Ml}$ and SP wrote the manuscript. LC and SA collected the clinical and laboratory data. GC he contributed to the discussion. GZ collected the bibliography. GBP reviewed the manuscript. Each author listed on the manuscript has seen and approved the submission of this version of the manuscript and takes full responsibility for the manuscript. All authors read and approved the final manuscript.

\section{Funding}

Not applicable.

\section{Availability of data and materials}

Not applicable.

\section{Declarations}

\section{Ethics approval and consent to participate}

Not applicable.

\section{Consent for publication}

Written informed consent was obtained from the patient's parents for the publication of this case report.

\section{Competing interests}

The authors declare that they have no competing interests.

\section{Author details}

'Department of Human Pathology in Adult and Developmental Age "Gaetano Barresi", Allergy Unit, University of Messina, Via Consolare Valeria 1, 98124 Messina, ME, Italy. ${ }^{2}$ Predictive and Preventive Medicine Research Unit, Multifactorial and Systemic Disease Research Area, Pediatric Allergology Unit, Bambino Gesù Children's Research Hospital (IRCCS), Rome, Italy.

\section{Received: 12 July 2021 Accepted: 13 September 2021}

Published online: 28 September 2021

\section{References}

1. Goetze S, Elsner P. Solar Urticaria. J Dtsch Dermatol Ges. 2015;13(12):1250-3. https://doi.org/10.1111/ddg.12809.

2. Maurer M, Metz M, Brehler R, Hillen U, Jakob T, Mahler V, et al. Omalizumab treatment in patients with chronic inducible urticaria: a systematic review of published evidence. J All Clin Immunol. 2018;141(2):638-64. https://doi. org/10.1016/j.jaci.2017.06.032.

3. Caffarelli C, Paravati F, El Hachem M, Duse M, Bergamini M, Simeone G, et al. Management of chronic urticaria in children: a clinical guideline. Ital Pediatr. 2019;45(1):101. https://doi.org/10.1186/s13052-019-0695-x.

4. Crisafulli G, Caminiti L, Chiera F, Arasi S, Salzano G, Panasiti I, et al. Omalizumab in children with severe allergic disease: a case series. Ital J Pediatr. 2019:45(1):13. https://doi.org/10.1186/s13052-019-0602-5.

5. Passanisi S, Arasi S, Caminiti L, Crisafulli G, Salzano G, Pajno GB. Omalizumab in children and adolescents with chronic spontaneous urticaria: case series and review of the literature. Dermatol Ther. 2020;33(4):e13489. https://doi. org/10.1111/dth.13489

6. Damiani G, Diani M, Conic RRZ, Colli C, Ferrucci S, Martina E, et al, Omalizumab in chronic Urticaria: an Italian survey. Int Arch Allergy Immunol. 2019:178(1):45-9. https://doi.org/10.1159/000492532.

7. Arasi S, Crisafulli G, Caminiti L, Guarneri F, Aversa T, Porcaro F, et al. Treatment with omalizumab in a 16-year-old Caucasian girl with refractory solar urticaria. Pediatr Allergy Immunol. 2015;26(6):583-5. https://doi.org/1 0.1111 pai.12413.

8. Snast I, Kremer N, Lapidoth M, Enk CD, Tal Y, Rosman Y, et al. Omalizumab for the treatment of solar urticaria: case series and systematic review of the literature. J Allergy Clin Immunol Pract. 2018;4(4):1198-204. https://doi.org/1 0.1016/j.jaip.2018.02.032.

9. Silva PM, Costa AC, Mendes A, Barbosa MP. Long-term efficacy of omalizumab in seven patients with treatment-resistant chronic spontaneous urticaria. Allergol Immunopathol (Madr). 2015;43(2):168-73. https://doi.org/1 0.1016/j.aller.2013.11.007
10. Saini SS, MacGlashan DW, Sterbinsky SA, Togias A, Adelman DC, Lichtenstein $L M$, et al. Down-regulation of human basophil lgE and FC epsilon RI alpha surface densities and mediator release by anti-lgE-infusions is reversible in vitro and in vivo. J Immunol. 1999;162:5624-30.

11. Holgate ST. New strategies with anti-lgE in allergic diseases. World Allergy Organ J. 2014;7(1):17. https://doi.org/10.1186/1939-4551-7-17.

12. Adachi M, Kozawa M, Yoshisue H, Milligan KL, Nagasaki M, Sasajima T, et al. Real-world safety and efficacy of omalizumab in patients with severe allergic asthma: a long-term post-marketing study in Japan. Respir Med. 2018;141:56-63. https://doi.org/10.1016/j.rmed.2018.06.021.

13. Santamaría L, Sánchez J. Eficacia a largo plazo del omalizumab en pacientes con queratoconjuntivitis vernal resistente a tratamiento convencional [Long-term efficacy of omalizumab in patients with conventional treatmentresistant vernal keratoconjunctivitis]. Rev Alerg Mex. 2018;65(2):192-6. https://doi.org/10.29262/ram.v65i2.292.

14. Passanisi S, Caminiti L, Zirilli G, Lombardo F, Crisafulli G, Aversa T, et al. Biologics in food allergy: up-to-date. Expert Opin Biol Ther. 2021;21(9):1-9. https://doi.org/10.1080/14712598.2021.1904888.

15. Zuberbier T, Aberer W, Asero R, Abdul Latiff AH, Baker D, Ballmer-Weber $B$ et al. The EAACI/GA²LN/EDF/WAO guideline for the definition, classification, diagnosis and management of urticaria. Allergy. 2018;73(7): 1393-414. https://doi.org/10.1111/all.13397.

16. Chang J, Cattelan L, Ben-Shoshan M, Le M, Netchiporouk E. Management of Pediatric Chronic Spontaneous Urticaria: a review of current evidence and guidelines. J Asthma Allergy. 2021;14:187-99. https://doi.org/10.2147/JAA. S249765.

17. Waibel $\mathrm{KH}$, Reese DA, Hamilton RG, Devillez RL. Partial improvement of solar urticaria after omalizumab. J Allergy Clin Immunol. 2010;125(2):490-1. https://doi.org/10.1016/j.jaci.2009.11.007.

18. Moncourier M, Assikar S, Matei I, Souyri N, Couture M, Rigot E, et al. Visible light-induced solar urticaria is improved by omalizumab. Photodermatol Photoimmunol Photomed. 2016:32(5-6):314-6. https://doi.org/10.1111/ phpp.12271.

19. Ertas R, Ozyurt K, Atasoy M, Hawro T, Maurer M. The clinical response to omalizumab in chronic spontaneous urticaria patients is linked to and predicted by lgE levels and their change. Allergy. 2018;73(3):705-12. https:// doi.org/10.1111/all.13345.

20. Straesser MD, Oliver E, Palacios T, Kyin T, Patrie J, Borish L. Serum IgE as an immunological marker to predict response to omalizumab treatment in symptomatic chronic urticaria. J Allergy Clin Immunol Pract. 2018;6:13861388.e1.

21. Haylett AK, Koumaki D, Rhodes LE. Solar urticaria in 145 patients: assessment of action spectra and impact on quality of life in adults and children. Photodermatol Photoimmunol Photomed. 2018;34(4):262-8. https://doi. org/10.1111/phpp.12385.

22. Can PK, Etikan P, Degirmentepe EN, Kocaturk E. Depression scores change significantly after omalizumab treatment in patients with chronic spontaneous urticaria. Asian Pac J Allergy Immunol. 2021. https://doi.org/1 0.12932/AP-180920-0965

\section{Publisher's Note}

Springer Nature remains neutral with regard to jurisdictional claims in published maps and institutional affiliations.

Ready to submit your research? Choose BMC and benefit from

- fast, convenient online submission

- thorough peer review by experienced researchers in your field

- rapid publication on acceptance

- support for research data, including large and complex data types

- gold Open Access which fosters wider collaboration and increased citations

- maximum visibility for your research: over $100 \mathrm{M}$ website views per year

At BMC, research is always in progress.

Learn more biomedcentral.com/submissions 